persuade potential purchasers that a psychotherapist was a worthwhile investment.

I wonder if people in other districts have had similar experiences.

Millbrook

G. O. Dubourg

King's Mill Hospital

Sutton-in-Ashfield NG17 4JL

\section{Rehabilitation and community care in psychiatry}

\section{DeAR SIRS}

General management, in all its aspects, is relevant to all branches of psychiatry. Apart, therefore, from being puzzled as to why the letter from Drs M. P. Sargeant and R. Ball (Psychiatric Bulletin, March $1991,15,173$ ) should have appeared under the above title, I would very much support the view that there is a need for information on general management as applied to psychiatry. I suspect this need might be greater among established consultants as one would hope that these topics are now being incorporated into the training programme for those aspiring to consultant status.

It has been for some time my contention that the College might be well placed to take the initiative in organising training sessions for psychiatrists on general management which, in practice, might be incorporated either into Divisional Meetings or into the Quarterly or Annual Meetings.

\section{Homefield and The Acre \\ Worthing, West Sussex \\ BN11 2HS}

T. PASTOR

\section{Of pegs and piles and poppycock}

\section{Dear Sirs}

Thank you for letting me see Dr Edward's letter (Psychiatric Bulletin, June 1991, 15, 368); there will, no doubt, be others in similar mode.

I wrote in support of colleagues who, like Dr Azuonye, have learnt, either by their own experience or from others that carpets have attractions that can sour. Dr Edwards is not in need of support for he aligns himself with those whose naive but insistent enthusiasm for these coverings causes a heavy heart for Dr Azuonye, myself and others.

Time will tell for Dr Edwards - he is likely to be around to learn - the enthusiastic managers will have rotated away long since. It is kind of Dr Edwards to invite me to his unit, an invitation I would like to take up during the second half of 1993 . He will find me wearing no peg, no blinkers, neither am I deaf and I retain both a sense of taste and an appetite for this work that has proved enduring. Among my purpose is to enable others to do the same!

DAVID J. Jolley

Withington Hospital

West Didsbury

Manchester M20 8LR

\section{Which section of the Mental Health}

Act-2 or 3?

DeAR SIRS

Had the framers of the Mental Health Act 1983 realised the continuous nature of the assessment process, the wording of Sections 2 and 3 would have been very different.

Section 2 would have provided to Assessment, or assessment followed by treatment, for a period of up to 28 days', and Section 3 would have been for 'Assessment, or assessment followed by treatment for a period greater than 28 days'.

This is the most meaningful way in which to use these two Sections of the Mental Health Act. Each time I admit a patient, on whom a diagnosis had been made, the admission is under Section 2. This applies also to those previously admitted under Section 3.

If the patient gets better during the initial 28-day period, I discharge him from detention or let the detention lapse. If, as we enter the fourth week of admission under Section 2, it is evident that the criteria for compulsory powers still apply, I recommend detention under Section 3.

The nationwide acceptance of this approach would make life considerably easier for consultant psychiatrists and approved social workers.

The London Hospital (St Clement's)

I. O. AZUONYE

$2 a$ Bow Road

London E3 4LL

\section{'An Angel at My Table'}

Dear Sirs

I read with interest Dr Bhugra's review of the film 'An Angel at My Table' (Psychiatric Bulletin, March 1991, 15, 190).

As one can understand, the film has received much acclaim in New Zealand, particularly for its vivid portrayal of the course of depressive illness in a young girl, her hospitalisation and her treatment.

Janet Frame's literary prowess is obviously apparent in her trilogy. The clarity she achieves in her various descriptions of events is superb. From a psychiatrist's point of view what better proof do we need that ECT has no lasting effects on memory!

S. R. KONAR

Waikato Hospital

Private Bag

Hamilton, New Zealand 